\title{
New Methods for Evaluation of Spent Fuel Condition during Long-Term Storage in Slovakia
}

\author{
M. Mikloš ${ }^{1}$ and V. Kršjak² \\ ${ }^{1}$ Reactor services division, Nuclear Research Institute Řež plc, Husinec-Řež 130, 25068 Řež, Czech Republic \\ ${ }^{2}$ Division of Safety of Future Nuclear Reactors, Institute for Energy, Joint Research Centre of the European Commission, \\ P.O. Box 2, 1755ZG Petten, The Netherlands
}

Correspondence should be addressed to M. Mikloš, mkl@ujv.cz

Received 13 March 2008; Accepted 11 June 2009

Recommended by Kannan Iyer

Experiences with an advanced spent nuclear fuel management in Slovakia are presented in this paper. The evaluation and monitoring procedures are based on practices at the Slovak wet interim spent fuel storage facility in NPP Jaslovské Bohunice. Since 1999, leak testing of WWER-440 fuel assemblies are provided by special leak tightness detection system "Sipping in pool" delivered by Framatomeanp with external heating for the precise defects determination. In 2006, a new inspection stand "SVYP440 " for monitoring of spent nuclear fuel condition was inserted. This stand has the possibility to open WWER-440 fuel assemblies and examine fuel elements. Optimal ways of spent fuel disposal and monitoring of nuclear fuel condition were designed. With appropriate approach of conservativeness, new factor for specifying spent fuel leak tightness is introduced in the paper. By using computer simulations (based on SCALE 4.4a code) for fission products creation and measurements by system "Sipping in pool," the limit values of leak tightness were established.

Copyright ( $) 2009$ M. Mikloš and V. Kršjak. This is an open access article distributed under the Creative Commons Attribution License, which permits unrestricted use, distribution, and reproduction in any medium, provided the original work is properly cited.

\section{Introduction}

The Interim Spent Fuel Storage Facility (ISFSF) in Jaslovské Bohunice [1-3] is an important component of the spent nuclear fuel management system. The facility has been used for storage purposes since 1987. ISFSF is a nuclear facility providing for a safe storage of the spent nuclear fuel from VVER-440 reactors for the time period of 50 years before the fuel is further processed in a reprocessing plant or appropriately disposed off.

It is necessary to keep the concentration of fission products in storage pools on the low level for assurance of acceptable activity of the coolant. This can be done with periodical monitoring of the fuel elements condition, defects identification, and closing of leaking assemblies or fuel elements, respectively, in special hermetic caskets. This was the main reason for including not only "Sipping in pool" system, but also inspection stand "SVYP-440" (Figure 1), into the ISFSF operation [4-7].

The system "Sipping in pool" was built and implemented in the storage facility operation in 1999 and since then, the important results have been measured. The system increases the temperature of the fuel assembly (by external heaters), which cause the increasing of the pressure inside fuel elements. If there is any leakage, increased pressure will cause higher fission product release. By measurement of released activity, the assembly tightness is determined.

Since December 2006, the new stand for VVER-440 fuel assemblies' inspection "SVYP-440" is in operation. By using several modules, it has ability to open and take the fuel assembly apart, so it can examine all fuel elements. If the defect is found, fuel element with defect is closed into the special hermetic case.

\section{Experimental}

Slovakia has more than 20 years of experience with spent fuel storage. Since beginning, there were no leakages detected during storage conditions. Even though the negative effects of fuel cladding are very low, however, due to degradation of Zirconium alloys after long periods of under water storage, there is a finite possibility of defect formation. It is also 


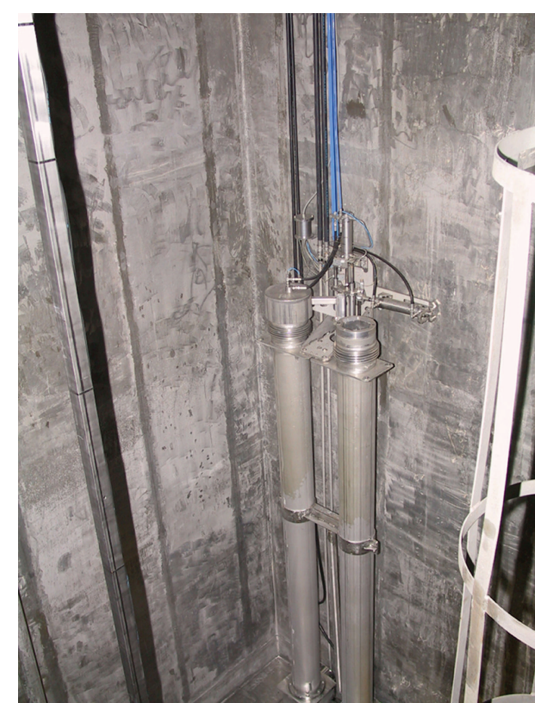

(a) Sipping in pool

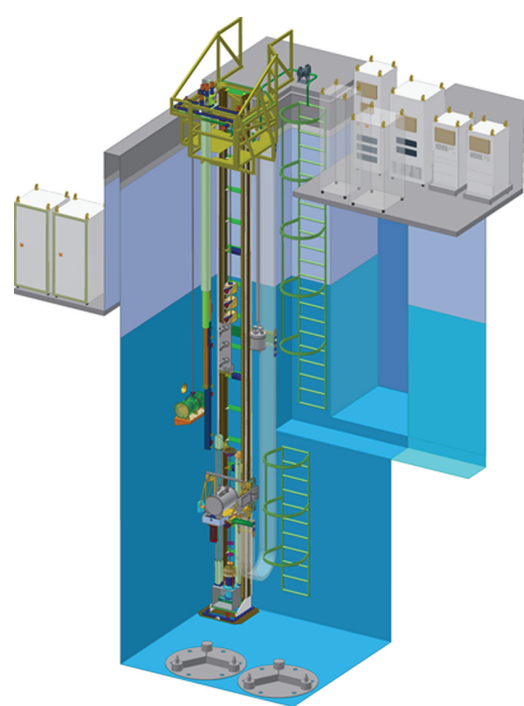

(b) SVYP-440

FIGURE 1: Equipment for VVER-440 spent fuel assemblies control in Slovakia.

difficult to estimate the long-term degradation process. With use of the systems like "Sipping in Pool" or "SVYP-440," the leakages of the fuel assembly can be detected.

In that case, it is necessary to have as conservative approach to the extent possible. If we compare the volume activity of released fission products around fuel assembly $A_{O}$ (measured by "Sipping in Pool") and the volume activity of fission products inside whole fuel assembly $A_{I}$ (calculated by SCALE code), we could estimate the fuel cladding condition. Therefore, we are introducing the fuel cladding leak tightness coefficient $k_{\mathrm{FCT}}$ :

$$
k_{\mathrm{FCT}}=\frac{A_{O}}{A_{I}} .
$$

For the calculations of volume activity of fission products (in particular, ${ }^{137} \mathrm{Cs}$ has been considered) inside whole fuel assembly, sequence ORIGEN-ARP have been used (for version SCALE 4.4a) $[8,9]$. As a simplification of the calculations, one model of fuel assembly has been used for all measured assemblies. This model, created by VUJE, a.s. company (Ing. Vladimír Chrapčiak, Ing. Radoslav Zajac, December 2002), is a standard model of VVER-440 fuel assembly, with the $\mathrm{UO}_{\mathrm{X}}$ fuel and $4.2 \%$ enrichment of ${ }^{235} \mathrm{U}$. Only burnup, power, effective days during operation and days during shut downs were unique for every assembly.

\section{Results}

After SCALE calculations of volume activity of ${ }^{137} \mathrm{Cs}$ inside the fuel assemblies, and measurements of volume activity of ${ }^{137} \mathrm{Cs}$ outside the fuel assemblies by "Sipping in Pool," 36 values of the fuel cladding leak tightness coefficients $k_{\mathrm{FCT}}$ have been obtained (Table 1). All values were described by distribution function (Figure 2) to determine the mean value $\mu$ and standard deviation $\sigma$. It means that all fuel assemblies with $k_{\mathrm{FCT}}=1.1 \cdot 10^{-10} \pm 6.5 \cdot 10^{-11}$, or $(\mu+1 \cdot \sigma)$,

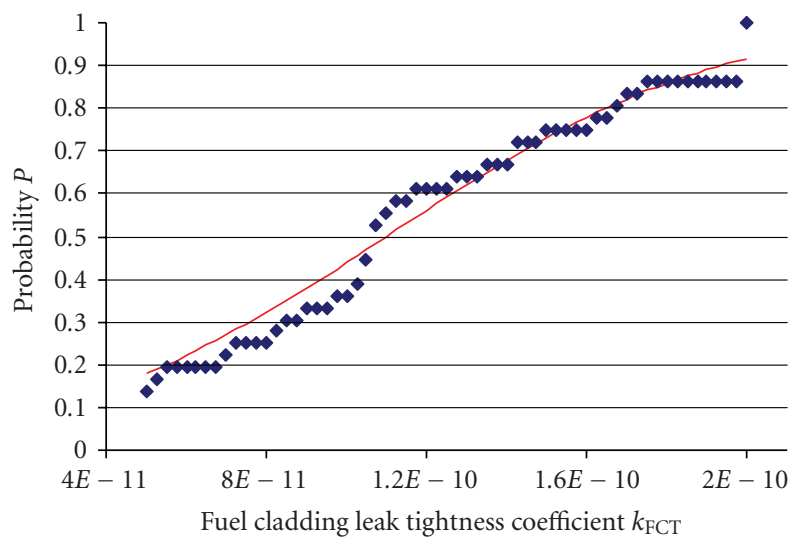

FIGURE 2: Distribution function of continuous variable $k_{\mathrm{FCT}}$.

are without any leakages. Fuel assemblies' producer criteria for the released $\gamma$ activity of fission products are $10^{-4} \mathrm{Ci} / \mathrm{L}$ $\left(3.7 \cdot 10^{6} \mathrm{~Bq} / \mathrm{L}\right)$. Because there were only small differences (less the $10^{1}$ ) between the measured summary gama activity and the separated cesium activity, we compared these two activities.

There were two limit values calculated:
(a) $k_{\mathrm{FCT}}=3 \cdot 10^{-10}$,
(b) $k_{\mathrm{FCT}}=8 \cdot 10^{-7}$.

The first value, $k_{\mathrm{FCT}}=1.1 \cdot 10^{-10} \pm 1.95 \cdot 10^{-10}=$ $3 \cdot 10^{-10}$, or $(\mu+3 \cdot \sigma)$ is from the statistical dispersion of distribution function of continuous $k_{\mathrm{FCT}}$, and means that $99.73 \%$ of the values are within 3 standard deviation. In other words, $k_{\mathrm{FCT}}=3 \cdot 10^{-10}$ means that with the probability of 99.73\% will be all measured and calculated assemblies tight. 
TABLE 1: Measured and calculated values of $A_{O}$ and $A_{I}$ and final calculation of $k_{\mathrm{FCT}}$.

\begin{tabular}{|c|c|c|c|c|c|}
\hline Number of FA & $A_{O}[\mathrm{~Bq} / \mathrm{L}]$ & $A_{O}[\mathrm{~Bq}]$ & $A_{I}$ to $1 \mathrm{kgU}[\mathrm{Ci}]$ & $A_{I}$ to $1 \mathrm{FA}[\mathrm{Bq}]$ & $k_{\mathrm{FCT}}$ \\
\hline 1 & 639 & 63900 & 82.7 & $3.678 \mathrm{E}+14$ & $1.73736 \mathrm{E}-10$ \\
\hline 2 & 609 & 60900 & 82.7 & $3.678 \mathrm{E}+14$ & $1.65579 \mathrm{E}-10$ \\
\hline 3 & 527 & 52700 & 115 & $5.11451 \mathrm{E}+14$ & $1.0304 \mathrm{E}-10$ \\
\hline 4 & 563 & 56300 & 113 & $5.02556 \mathrm{E}+14$ & $1.12027 \mathrm{E}-10$ \\
\hline 5 & 535 & 53500 & 113 & $5.02556 \mathrm{E}+14$ & $1.06456 \mathrm{E}-10$ \\
\hline 6 & 609 & 60900 & 118 & $5.24793 \mathrm{E}+14$ & $1.16046 \mathrm{E}-10$ \\
\hline 7 & 421 & 42100 & 86.4 & $3.84255 \mathrm{E}+14$ & $1.09563 \mathrm{E}-10$ \\
\hline 8 & 584 & 58400 & 81.3 & $3.61574 \mathrm{E}+14$ & $1.61516 \mathrm{E}-10$ \\
\hline 9 & 483 & 48300 & 102 & $4.53635 \mathrm{E}+14$ & $1.06473 \mathrm{E}-10$ \\
\hline 10 & 539 & 53900 & 86.4 & $3.84255 \mathrm{E}+14$ & $1.40271 \mathrm{E}-10$ \\
\hline 11 & 484 & 48400 & 80.8 & $3.5935 \mathrm{E}+14$ & $1.34688 \mathrm{E}-10$ \\
\hline 12 & 536 & 53600 & 80.8 & $3.5935 \mathrm{E}+14$ & $1.49158 \mathrm{E}-10$ \\
\hline 13 & 627 & 62700 & 100 & $4.4474 \mathrm{E}+14$ & $1.40981 \mathrm{E}-10$ \\
\hline 14 & 135000 & 13500000 & 103 & $4.58082 \mathrm{E}+14$ & $2.94707 \mathrm{E}-08$ \\
\hline 15 & 6740 & 674000 & 109 & $4.84767 \mathrm{E}+14$ & $1.39036 \mathrm{E}-09$ \\
\hline 16 & 74000 & 7400000 & 109 & $4.84767 \mathrm{E}+14$ & $1.52651 \mathrm{E}-08$ \\
\hline 17 & 372 & 37200 & 79 & $3.51345 \mathrm{E}+14$ & $1.05879 \mathrm{E}-10$ \\
\hline 18 & 366 & 36600 & 79 & $3.51345 \mathrm{E}+14$ & $1.04171 \mathrm{E}-10$ \\
\hline 19 & 277 & 27700 & 122 & $5.42583 \mathrm{E}+14$ & $5.10521 \mathrm{E}-11$ \\
\hline 20 & 441 & 44100 & 122 & $5.42583 \mathrm{E}+14$ & $8.12779 \mathrm{E}-11$ \\
\hline 21 & 461 & 46100 & 125 & $5.55925 \mathrm{E}+14$ & $8.29249 \mathrm{E}-11$ \\
\hline 22 & 288 & 28800 & 132 & $5.87057 \mathrm{E}+14$ & $4.90583 \mathrm{E}-11$ \\
\hline 23 & 437 & 43700 & 77.7 & $3.45563 \mathrm{E}+14$ & $1.2646 \mathrm{E}-10$ \\
\hline 24 & 310 & 31000 & 77.7 & $3.45563 \mathrm{E}+14$ & $8.97087 \mathrm{E}-11$ \\
\hline 25 & 505 & 50500 & 111 & $4.93661 \mathrm{E}+14$ & $1.02297 \mathrm{E}-10$ \\
\hline 26 & 346 & 34600 & 111 & $4.93661 \mathrm{E}+14$ & $7.00885 \mathrm{E}-11$ \\
\hline 27 & 854 & 85400 & 114 & $5.07004 \mathrm{E}+14$ & $1.68441 \mathrm{E}-10$ \\
\hline 28 & 238 & 23800 & 114 & $5.07004 \mathrm{E}+14$ & $4.69425 \mathrm{E}-11$ \\
\hline 29 & 320 & 32000 & 75.6 & $3.36223 \mathrm{E}+14$ & $9.51748 \mathrm{E}-11$ \\
\hline 30 & 182 & 18200 & 75.6 & $3.36223 \mathrm{E}+14$ & $5.41307 \mathrm{E}-11$ \\
\hline 31 & 278 & 27800 & 126 & $5.60372 \mathrm{E}+14$ & $4.96099 \mathrm{E}-11$ \\
\hline 32 & 150 & 15000 & 118 & $5.24793 \mathrm{E}+14$ & $2.85827 \mathrm{E}-11$ \\
\hline 33 & 366 & 36600 & 119 & $5.29241 \mathrm{E}+14$ & $6.91557 \mathrm{E}-11$ \\
\hline 34 & 105 & 10500 & 124 & $5.51478 \mathrm{E}+14$ & $1.90398 \mathrm{E}-11$ \\
\hline 35 & 2030 & 203000 & 74.5 & $3.31331 \mathrm{E}+14$ & $6.1268 \mathrm{E}-10$ \\
\hline 36 & 3880 & 388000 & 74.5 & $3.31331 \mathrm{E}+14$ & $1.17103 \mathrm{E}-09$ \\
\hline
\end{tabular}

The second value is calculated with use of fuel assemblies' producer criteria $A_{O P}=3.7 \cdot 10^{6} \mathrm{~Bq} / \mathrm{L}$

$$
k_{\mathrm{FCT}}=\frac{A_{O}}{A_{I}}=\frac{3.7 \cdot 10^{8} \mathrm{~Bq}}{4.4655 \cdot 10^{14} \mathrm{~Bq}}=8.06 \cdot 10^{-7},
$$

where $A_{O}=A_{O P}^{*} V_{s}, V_{s}$ : volume of the Sipping casket [3, 4], and $A_{I}$ : average value of the calculated $A_{I}$ (Table 1 ).

By considering by this value, we set the final limit intervals:

(1) $\left(0-3 \cdot 10^{-10}\right)$ : values of the fuel cladding leak tightness coefficient for tight fuel assembly- $k_{\mathrm{FCT}}(\mathrm{T})$,
(2) $\left(3 \cdot 10^{-10}-8 \cdot 10^{-7}\right)$ : values of the fuel cladding leak tightness coefficient for fuel assembly suspicious from leakage- $k_{\mathrm{FCT}}(\mathrm{SL})$,

(3) $\left(8 \cdot 10^{-7}-1\right)$ : values of the fuel cladding leak tightness coefficient for fuel assembly with leakage$k_{\mathrm{FCT}}(\mathrm{L})$.

The optimal use of the cladding leak tightness coefficient $k_{\mathrm{FCT}}$ is its application during periodical monitoring of fuel assemblies. Because of the low level of summary $\gamma$ activity in the coolant, monitoring of 6 fuel assemblies at ISFSF in Jaslovské Bohunice is provided once per year. Two assemblies are marked as reference, other 4 assemblies are chosen randomly. For those two reference assemblies, 


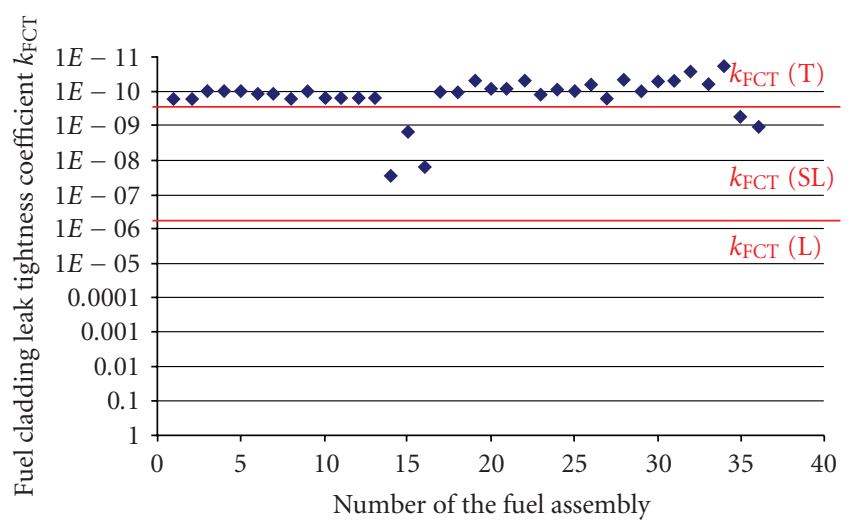

Figure 3: Limit values for the fuel cladding leak tightness coefficient $k_{\mathrm{FCT}}$.

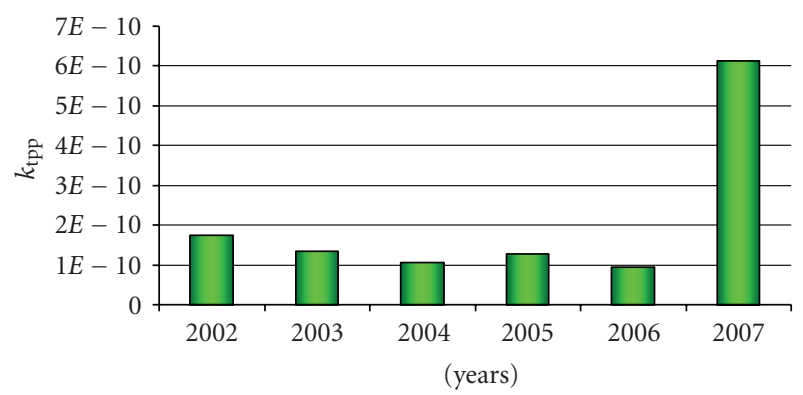

Figure 4: Values of $k_{\mathrm{FCT}}$ for reference FA number 1.

values of the cladding leak tightness coefficient $k_{\mathrm{FCT}}$ were calculated. For both assemblies (Figures 4 and 5), the values of $k_{\mathrm{FCT}}$ are about $1.2 \cdot 10^{-10}$. Only during last measurement, few deviations have been observed. The deviation for first assembly is $+7.73 \cdot \sigma$, and for second assembly it is +16.3 . $\sigma$. This means, that both fuel assemblies are susceptible to the leak tightness. However, during measurements in 2007, values of $k_{\mathrm{FCT}}$ increased for every measured assembly. So, the "jumps" can be caused by incorrect measurements by "Sipping in Pool."

\section{Conclusions}

From the nuclear safety point of view, it is necessary to keep the fission products inside the fuel elements and to prevent their escape into environment not only during reactor operation or fuel transport, but also during the longterm storage of spent nuclear fuel. Therefore, the effective leak tightness monitoring system at all fuel interim storages is necessary. The designed system from the 80 s at the Slovak wet interim storage facility did not assure this task at the desired level, so the system "Sipping in Pool" was implemented in 1999. After several years of its operation, performed measurements showed that this system is highly effective equipment for fuel cladding defects detection. Since 2006 a new inspection stand "SVYP-440" for monitoring of spent nuclear fuel condition is used as well.

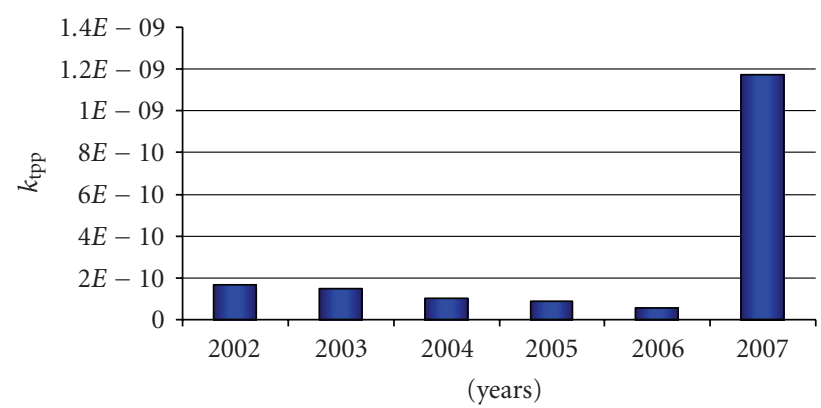

Figure 5: Values of $k_{\mathrm{FCT}}$ for reference FA number 2.

New factor for specifying of spent fuel leak tightness has been introduced. Using the computer simulations (based on SCALE 4.4a code) for fission products creation and measurements by the system "Sipping in Pool," the limit values of the cladding leak tightness coefficient $k_{\mathrm{FCT}}$ has been defined. It is a tool, which is used as additional information, describing fuel cladding leak tightness criteria. Forwardlooking, the authors expect that the mean value of $k_{\mathrm{FCT}}$ will oscillate about $10^{-10}$. Contingent deviations could be caused by incorrect measurements by "Sipping in Pool," or using of incorrect fuel assembly model for SCALE calculations. Also, the leak tightness coefficient $k_{\mathrm{FCT}}$ will depend on the pool water cleaning system. Depending on the residual activity in the pool, the values of $k_{\mathrm{FCT}}$ will change. Therefore, further research is needed.

\section{Acknowledgment}

The financial contributions from Grants VEGA 1/3188/06, 1/0129/09, and EC-6FP COVERS are acknowledged.

\section{References}

[1] Regulations for the Safe Transport of Radioactive Material, IAEA Safety Standards Series, International Atomic Energy Agency, Vienna, Austria, 1996.

[2] M. Šeliga and V. Slugeň, "Radioactive waste and spent fuel," EE-Odborný Časopis pre Elektrotechniku a Energetiku, vol. 4, pp. 50-51, 1998 (Slovak).

[3] V. Slugeň, et al., "Long-term storage of the spent nuclear fuel in Slovakia," Research Report, FEI STU Bratislava, Bratislava, Slovakia, November 1998.

[4] V. Slugeň, M. Mikloň, B. Božik, and D. Važina, "Monitoring and leak testing of WWER-440 fuel assemblies in Slovak wet interim spent fuel storage facility," Acta Montanistica Slovaka, vol. 12, pp. 187-191, 2007.

[5] V. Slugeň, I. Smieško, and D. Belko, "VVER-440 fuel leak testing experience at NPP Jaslovské Bohunice," Journal of Electrical Engineering, vol. 46, pp. 29-31, 1995.

[6] V. Slugeň, M. Kalousek, and M. Rajčok, "Thermophysical verification of continuous hermetic sealling of fuel elements by coating control in the VVER-440 nuclear reactor," Journal of Radioanalytical and Nuclear Chemistry, vol. 164, no. 2, pp. 71-80, 1992.

[7] V. Slugeň, "Mast-sipping for VVER-440 fuel assemblies," Nuclear Engineering International, vol. 39, pp. 29-31, 1994. 
[8] "SCALE: a modular code system for performing standardized computer analyses for licensing evaluation," Tech. Rep. NUREG/CR-0200, Rev. 6, ORNL/NUREG/CSD-2/R6, 1998.

[9] S. M. Bowman and L. C. Leal, "ORIGEN-ARP-automatic rapid process for spent fuel depletion, decay, and source term analysis," NUREG/CR-0200, Revision 6, vol. 3, S.D1, ORNL/NUREG/CSD-2/V3/R6, 1998. 

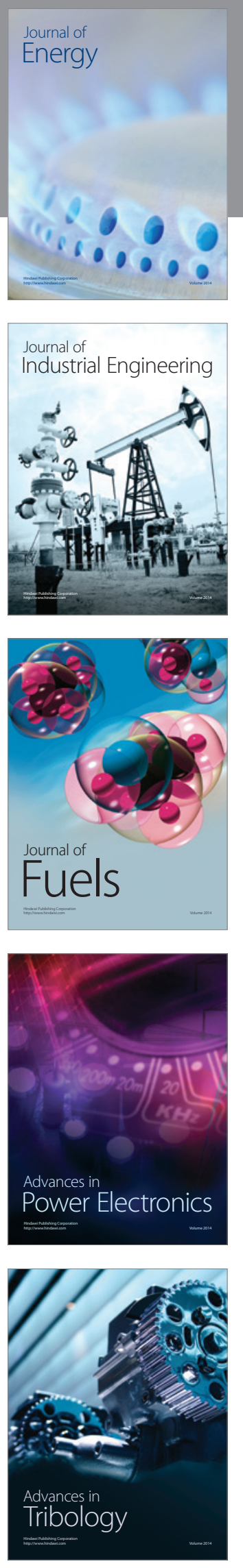
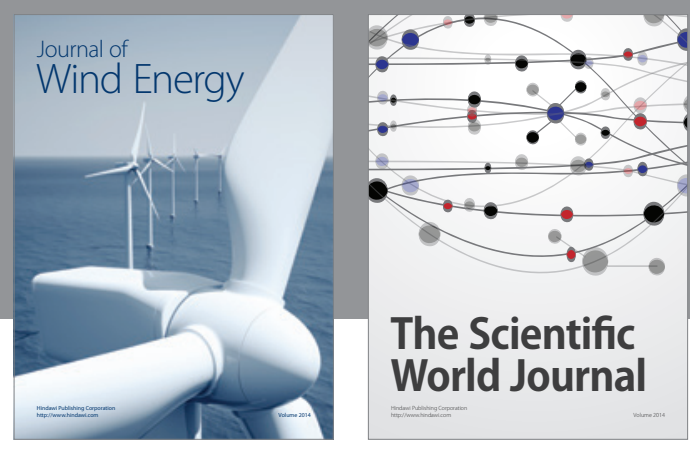

The Scientific World Journal

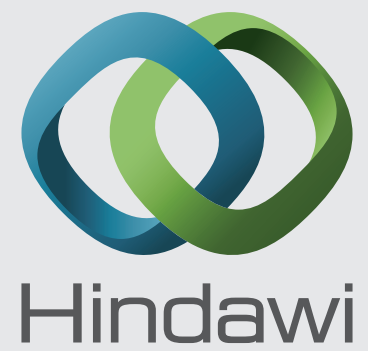

Submit your manuscripts at http://www.hindawi.com
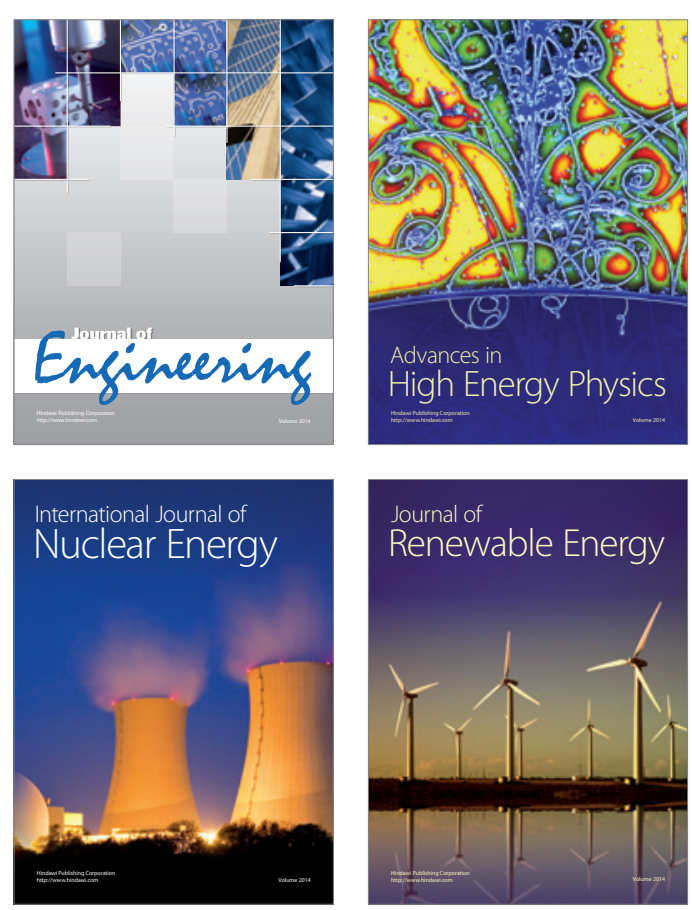

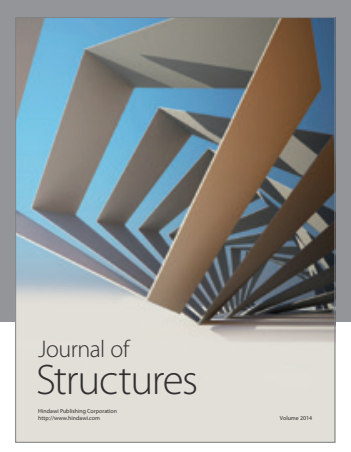

Rotating
Mechinery
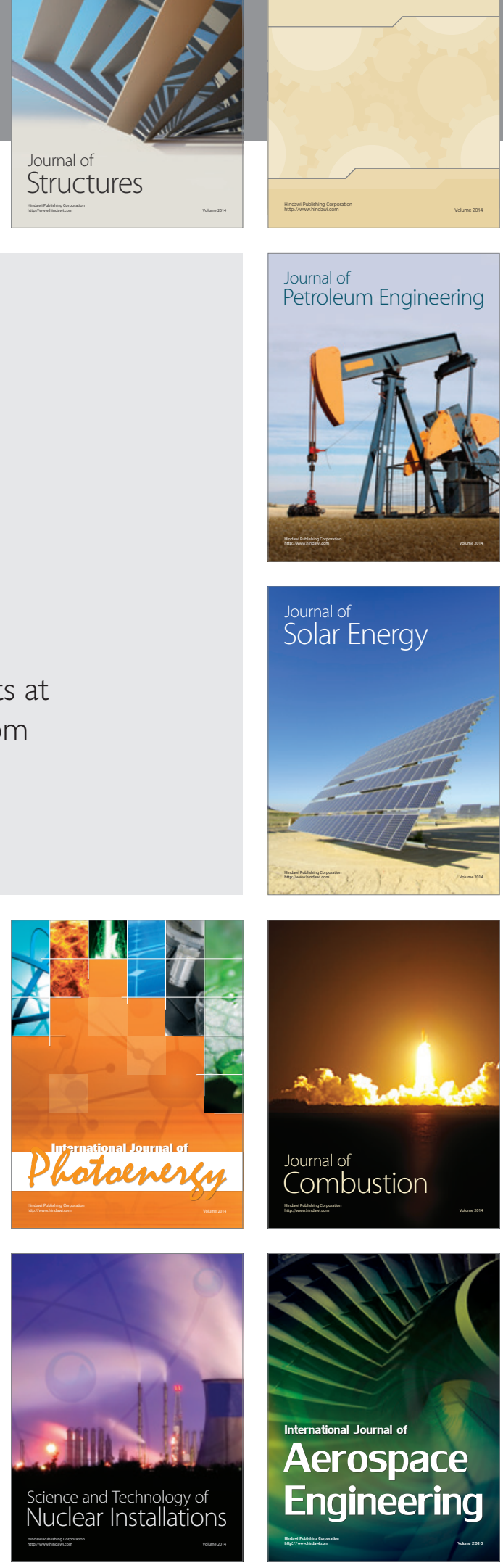